\title{
Katse mõista keraamikut
}

Käesolev artikkel on etnoloogi katse mõista kunstnikku, mitte kunstiteaduslik ülevaade Maanus Mikkeli loomingust.

Keraamikal ei ole eesti rahvakunstis olnud kunagi arvestatavat traditsiooni. Eestlane väljendas oma kunstimeelt rohkem puud lõigates või rauda tagudes. Nahakunst oli võrreldes teistega nõrguke ja kaunid hõbeehted väljendasid küll eestlase maitset, aga olid põhiliselt õppinud hõbeseppade kätetöö. Keraamika vallas hakati alles 19. sajandi teisel poolel Kagu-Eestis lihtsat laiatarbekaupa tegema ja oma kraami pakkuvad potisetud kogusid kuulsust kaugemalgi. Nii et keraamika puhul ei saa juttugi olla mingist rahvapärasest traditsioonist, vaid Eestis suhteliselt noorest kunsti või tarbekunsti (kuidas kellelegi meeldib) alast.

1956. aastal Tartus sündinud kunstnik õppis Tartu Miina Härma kooli lõpetamise järel aastatel 1972-1976 Tartu Kunstikoolis puidu kunstilist kujundamist ja 1978-1988 kunstiakadeemias keraamikat. Ta on töötanud koondises Ars, Artes ja Studio Ceramicumis. Alates 2001. aastast vabakutseline keraamik. 1990. aastatest alates on keraamik Maanus Mikkel ehk Mann esinenud arvukatel näitustel:

- 1990 ühisnäitus Piret Veski, Pille Kängsep Tartu kunstimajas ja Tallinnas Kiek in de Kökis;

- 1991 "Urilugu" koos Kaido Kasega Tartu Kunstimuuseumis;

- 1992 "Kade keraamik" Tartus Sinimandria galeriis ning "Savi ja raud" koos Ivar Feldmaniga Illegaardi galeriis;

- 1994 "Keraamika" Tallinna galeriis Sammas ja Tartus Rüütli galeriis;

- 1995 ühisnäitus Piret Veski ja Kaido Kasega Kuressaare lossis;

- 1997 "Raud ja savi" koos Ivar Feldmaniga Tartus Mikkeli galeriis;

- 1998 isikunäitus Tõrva Kontsertsaalis;

- 2001 “Urujutt” Tartu Kunstimajas ja Eesti saatkonnas Riias;

- 2004 "Embused" Tartus Mikkeli galeriis.

Esinenud veel Tartu ja vabariiklikel tarbekunsti-ja keraamikanäitustel, samuti Soomes, Norras ja Rootsis.

http://haldjas.folklore.ee/tagused/nr29/mikkel.pdf 
Maanus Mikkeli looming on läbi aja, hoolimata selle vältel muutunud väljenduslaadist, olnud sellise alatooniga, mille kohta on öeldud küll etnokunst, küll ugri-mugri värk. Pole need ju mingid terminid, kuid tekitavad ometi teatud kindla paradigmatunnetuse. Täiesti art déco joonega taldrik kannab äkki nime "Lõuguti". Kunstniku vanaisal olla just selline linalõuguti rehe all olnud.

Et kunstnikust paremini aru saada, olen kasutanud etnoloogi tuntud töövõtet ehk lasknud uurimisobjektil endal rääkida, esitades vaid lihtsaid küsimusi.

Piret Õunapuu: Kas sinu maailma asjadest arusaamise algusel on ka mingit oma pere märki küljes? Oli ja on sinu ema Helju Mikkel üks meie rahvakultuuri kuulsamaid kandjaid.

Maanus Mikkel: Kasvasin ju suurema osa ajast kuni koolini maal. Mis seal maal spetsiaalselt seda rahvuslikkust... Maa elu oli helge ja lahke, aga eks ta olnud karm ikka ka. Roostevett just varbavahel ei olnud, aga õiendasid [=tegid tööd] juba varakult. Vanaisa oli see, kes mõtet suunas. See oli emapoolne vanaisa, isapoolset ma nagu õieti ei mäletagi.

Emal käisid rahvatantsijad kogu aeg kodus. Ikka paarkümmend inimest korraga ja muidugi näidati neile ka mind. Või mulle nad meelde jäid! Tulemus oli see, et kui siis linna peal juhtusid midagi tegema, oli sul kogu aeg sada silma peal. Sa ei olegi midagi hullu teinud, aga paari päeva pärast hakkab: kus sa siis olid ja mida tegid? Hea, kui üldse tuli midagi meelde, kuid kodus öeldi, et teame küll! See oli pigem needus. Koolis sain ma ka mõnitada, et tantsumemme laps: "Mann, pane polkat ka!"

Maal olid ilusad talveõhtud, elektrit ei olnud ja õhtul pandi põlema õlilambid. Pliit ju küdes kogu aeg, seakartul podises. Vanaisa suitsetas seal pliidi ees ja askeldas kogu aeg. Magama veel ei mindud ja siis oli minul nikerdamise aeg. Olin siis juba indiaanlasi lugenud ja kõrvetasin kuuma kõvera traadijupiga oma tomahoogile mustreid peale. Kukelt kiskusin sulgi. Selles suhtes oli kihvt, et vanad maal ei keelanud. Vanaisa oli selline, et kui sul ikka isu oli, võisid noa ja haamri kallale minna. Oluline oli, et panid asja pärast sinna, kust selle võtsid. Mäletan, kui ma endale kunagi karke [= kompasid] tegin. Kaikad mul olid, aga naeltega panin mööda: teadsin, mis on head ja mis on kehvad. Võtsin neid kehvapoolseid, lõin, ja need ei läinud õieti sisse, läksid kõik kõveraks. Vanaisa 


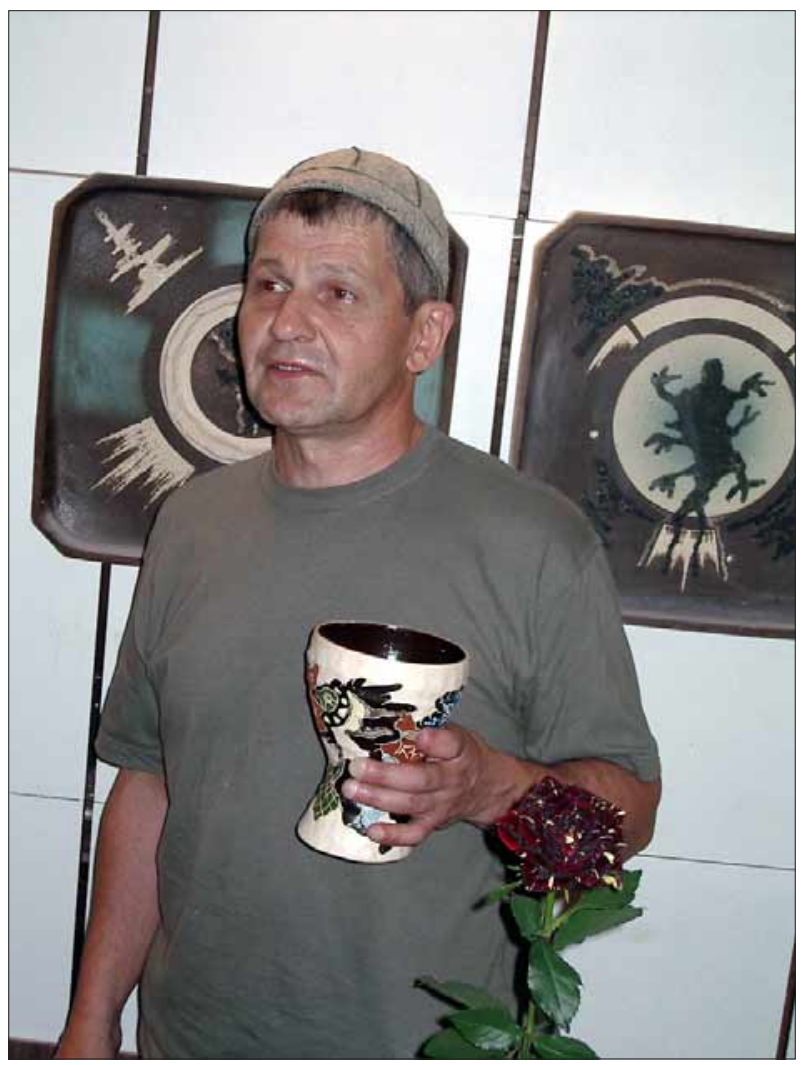

Foto 1. Keraamik Maanus Mikkel oma ateljees 2004. aastal. Jaan Soplepmanni foto.

läks mööda, vaatas ning tal oli niisugune väike muiatus suunurgas, aga ega ta ei ütelnud ka midagi. Siis tuli natukese aja pärast tagasi ja ütles: "No kulla poja, kui maha satad, siis lõhud oma perse ka ära. Võta need valla ja teeme uueste."

Vanaema oli juba väiksena suur lugemishull olnud. Ajalehesabas ilmunud jutud olid vihikuks köidetud. Ei tea, kust külapoest ta oli need saanud, ja neid üritas ta isegi lehmalüpsi ajal lugeda. Tal oli selliseid lüürilisi asju alles. Vallimäe neitsi. Mulle ka meeldis hirmsasti lugeda ja vanaema andis mulle lugusid kurikuulsast röövlist ja salakütist Antonist ja kaks paksu raamatut 13 aastat armastust kaljukoopas - kõik see oli gooti kirjas. Vanaema oli enne rääkinud, 


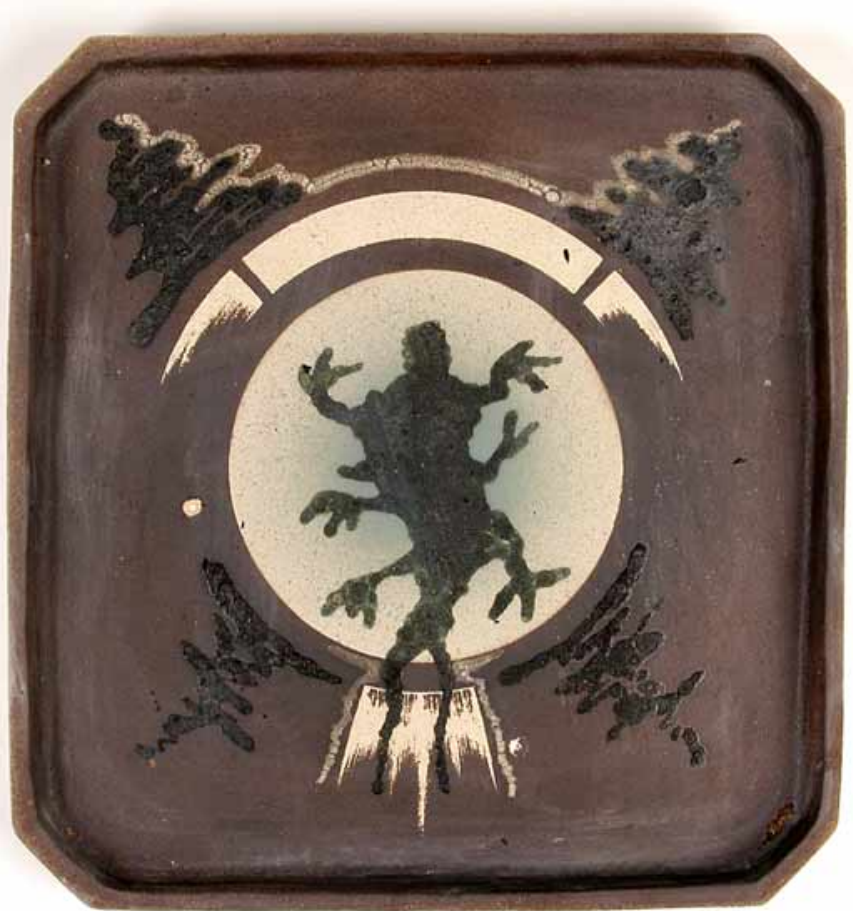

Foto 2. Maanus Mikkel. "Rabane”. Šamott, madalkuumus. 1992. Anu Ansu foto.

mis seal oli. No nii põnev oli ja siis ma nuiasin, et tahan seda ise lugeda. Mingeid tähti ta mulle alguses näitas ka. $S$ ja $T$ läksid mul kogu aeg segi, aga kuna oli niivõrd põnev, õppisin tänu sellele gooti kirja lugemise ära.

Vanaemal oli kena teooria: vits on latse rohi ja tuleb anda siilipidi peenikese vitsaga, et konti ei rikuks. Nagu talus, kaks-kolm nähvi, rohkem ei või. Muidu harjub ära, läheb tuimaks. Vahel sain päevas 2-3 korda vitsu, kui halb päev oli. Ja andeks pidin paluma. See asi mulle ei istunud. Sul oli ikka oma õigus, ja jonn lööb vahel siiamaani välja.

8-9 kuud aastast olin kuni kooliminekuni maal. Lumest lumeni. Linnas oli raskem: ei tohtinud midagi, ei teadnud täpselt, millal sa välja said jne. Maal oli sul maailm, nii kaugele kui silm ulatus või lallu tatsuda jaksas. 
Koerakülast edasi suure tamme poole läks alguses üsna lai tee, aga mida kaugemale kõnniti, seda pisemaks rajaks see muutus. Hiljem, metsa vahel kippus teine vahetevahel päris ära kaduma. Metsavarastele oli see suur needus, kui neil mütsid jälle peas põlema läksid ja nad ummisjalu jõe poole kihutasid. Jõnnu elas seal tagapool mäekünka peal ja nautis tihti läbi metsa tuhisevaid suitsujugasid. Targemad küll taipasid mütsi maha visata, kus see kohe ära kustus, aga tegelikult ükski aus varas nii ei teinud, ilma peakatteta ametimees oli natuke naeruväärne.

Jõnnu korjas vahel neid mütse ja riputas aiateibasse ritta. Veemees käis tal neljapäeviti külas ja siis nad jõid õlut ja pritsisid veejugadega kaabude pihta märki. Veemees oli muidu üsna tõsine tegelane, aga kui hilises õhtupäikeses vikerkaarevärvilised veejoad aialt mütse niitsid, siis lõkerdas ta päris suure häälega. Nõnda nad siis elasid ja olid, kuni ühel õhtul Veemees ootamatult Jõnnu poole tuli. Ei olnud neljapäev ega midagi ja vanamees ise kangesti morn. Istus tüki aega vaikselt paku peal, sikutas vuntse ning lõpuks hakkas tasapisi pajatama. Et jõe ääres on juba mitu päeva võorraid jälgi, mida tema enne näinud pole. Kõik pardid on ära hirmutatud, aga ükski ei oska öelda, mis või kes see hirmuta-

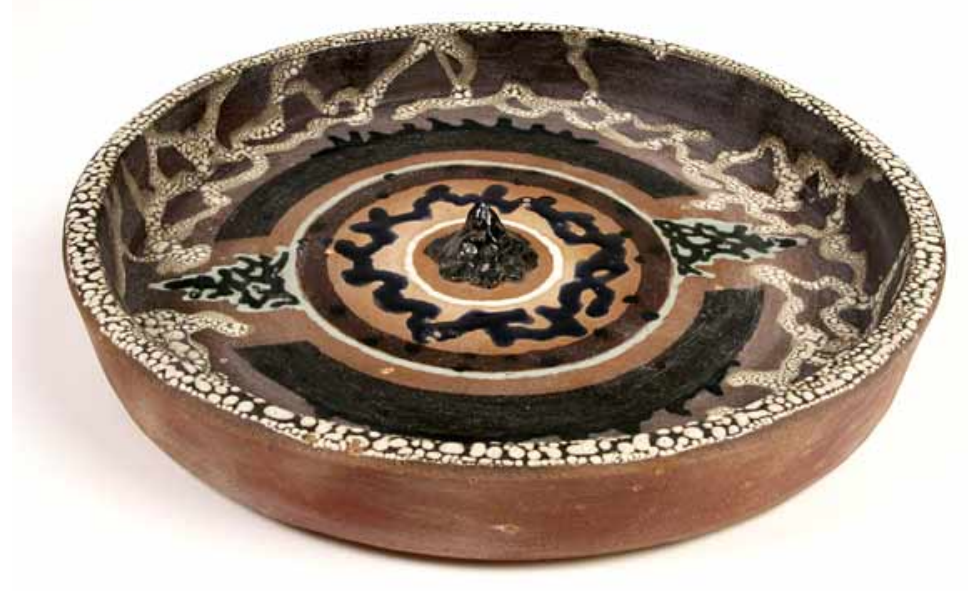

Foto 3. Maanus Mikkel. "Saar". Madalkuumus. 1993. Anu Ansu foto. 
ja on. Tagatipuks tuli ta lagedale kõige hullemaga, nimelt oli tagakambri kellakapist kadunud Veemehe kallis karikas, mida ta hoidis nagu silmatera. Toda kallisasja polnud Jõnnu poole pilgugagi näinud, eks ta üks salaasi olnud, mille abil Veemees oma töid ja tegemisi tegi. Igatahes mure oli suur ja paistis igast otsast välja ka. Natuke oli ta ikka asja uurinud, arvas ta, et sinna Suuresoo tagumise järve äärde on midagi tekkinud, midagi niisugust, mis seal mitte olema ei peaks. Äkki oleks Jõnnu nii hea mees, et tuleks toeks asja uurima. Ega Veemees nü̈̈d kõige aremate killast olnud, pigem kardeti teda ennast natuke, võimu ja väge oli tal üksjagu. Nii et lugu tundus päris tõsine olevat ja ega Jõnnul muud üle jäänud kui hädalist aidata. Lepitigi kokku, et öö tuleb üle oodata ja siis varahommikul vaatama minna, millega tegemist. Veemees kadus käbedalt õhtuhämarusse, tal olla veel enne kuutõusu ühtteist toimetada. ${ }^{1}$

Sotsialiseerumine on Maanus Mikkeli puhul olnud pikk ja keeruline ja läinud üle kivide ja kändude. Eesti Riiklikus Kunstiinstituudis õppiminegi võttis kokku aega kümme aastat. Selle aja sisse mahtus ka üks kunstitudengitele tavaks saanud põhjarahvaste juures

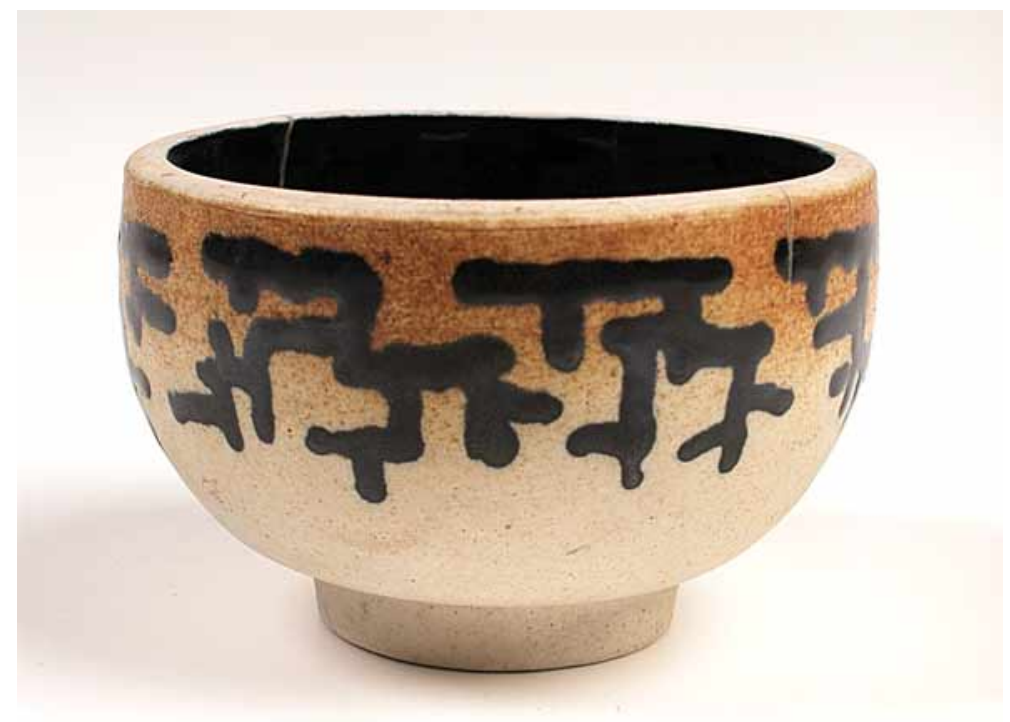

Foto 4. Maanus Mikkel. "Põdraline". Kõrgkuumus. 1989. Anu Ansu foto. 

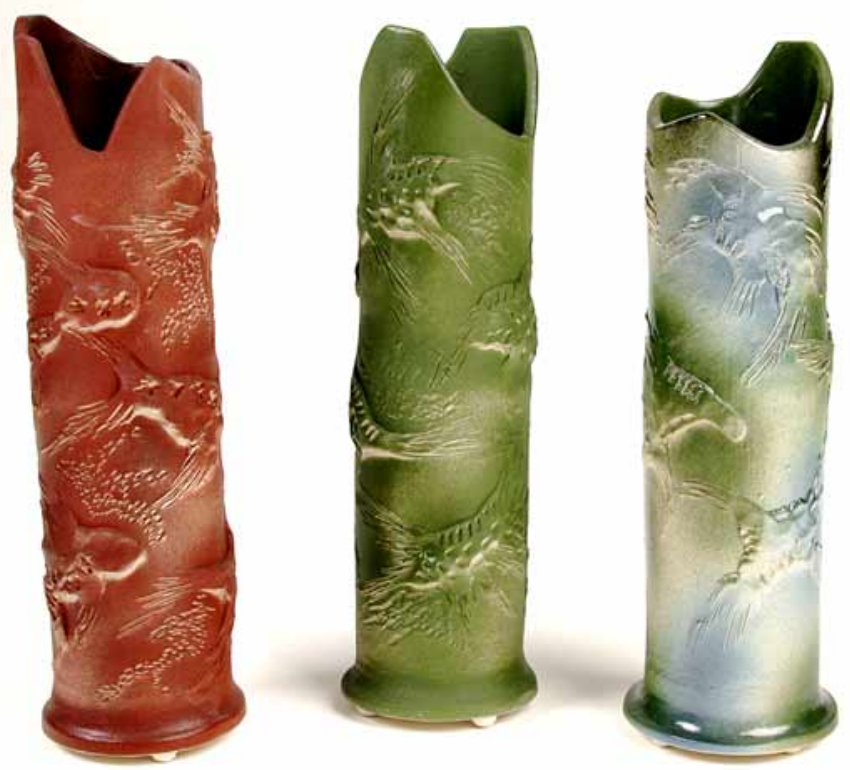

Foto 5. Maanus Mikkel. "Vudilased". Madalkuumus. 2003. Anu Ansu foto.

käimine. Suuremat süvitsi minekut ega Üliõpilaste Teadusliku Ühingu (ÜTÜ) referaati sellest küll ei tulnud, aga külge jäi midagi kindlasti. Vähemasti mällu, sest põhjarahvastele omaseid jooni hakkas tema loomingusse ilmuma alles aastate pärast. Hoolimata keraamika õppimisest oli kooliaegne huvi ja suund hoopis graafika, mis tundus andvat palju enam võimalusi. Nii sündisid taldrikud ja potid, mis mõjusid oma graafilise joone tõttu mõnusalt äraspidistena. Rohkem sahtlisse ja sõpradele kui avalikkusele sai tehtud ka väikeseformaadilisi graafilisi lehti.

Alles pärast kooli lõpetamist, 33-aastasena, hakkas ta vaatama, kas ta seda maailma üldse tahabki. Vast piisas siis sinnani sellest oma maailmast, kuhu oli alati võimalus põgeneda. Kui just kunsti ei saanud teha, siis lugeda sai alati. Ja kirjutada.

Järgmisel hommikul lõi Jõnnu silmad varakult lahti. Kukk norises veel orrrel ja koit kobistas kusagil tagahoovis, ise pahuralt 
pomisedes. Öö ei olnud eriti rahulik, kummalised unenäod ja iseäralik rahutus olid une uue kuиe üsna korralikult ära rikkunud.

Tee suure soo peale oli pikk ja tü̈̈tult vesine, parmud ja kuum päike peale selle. Aga lubatud oli, pealegi ütles mingi sisemine tunne Jõnnule, et ega see minemata jätmine ka asja paranda. Nii ta siis ajas tasapisi riided selga ning läks ja kolistas veidi aega pööningul. Kusagil nurgas pidi seal vedelema vanaisa rännutümikas, millega see omal ajal pikad maad maha oli kõndinud. Lõpuks Jõnnu selle katuse vahelt leidiski. Tolmune ja siledaks kulunud teine oli, aga muidu igati tubli tükk, pakkus kõndijale tuge ja kindlas käes võis tast muudki kasu olla. Söögikraami ei viitsinud Jõnnu otsima hakata, Veemehel oli nagunii paremaid palasid rännukotist võtta, kui pikemaid käimisi ette tuli. Nii ta siis jättis ukse kuke jaoks praokile ja kõndis künkast alla jõe poole.

Päike hakkas ennast tasapisi metsa tagant välja vinnama ja üksiku tossava mütsi suits segunes kerkiva uduga. Päev tõotas kaunis tulla ja Jõnnu süda muutus tasapisi muretumaks. Too karika kadumine oli üksjagu imelik küll, aga miski seletus pidi ju ometi asjale leiduma. Pealegi oli tagumise järve ääres üsna häid

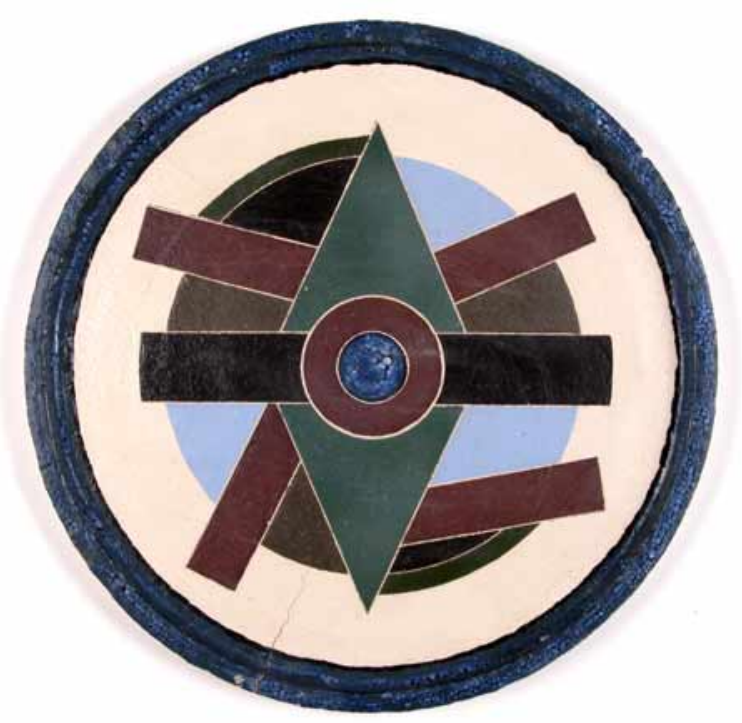

Foto 6. Maanus Mikkel. “Lõuguti”. Madalkuumus. 2000. Anu Ansu foto. 
kalapüügikohti ja Jõnnu lootis, et kui öö peale jäädakse, saab koos Veemehega vähemalt tubli kõhutäie värsket vitsutada.

Jõgi hakkas puude vahelt paistma ja seal see Veemehe maja oligi, kui seda nii võis nimetada. Osalt vaiade peal, osalt nagu parvel ja mingi osaga sellest oli peremees vahel päevade kaupa kadunud. Igatahes praegu ajas korsten tasapisi suitsu välja ja silla ääres seisis suur kõverik kogu. Jõnnu hõorrus paar korda silmi, aga ega seal eksimisvõimalust eriti olnud ja ärevus hakkas jälle tasapisi hinge tekkima. Krobalikku oli ta metsa vahel paar korda kohanud, kui see puuvarastele tuult alla tegi, ja teist temasarnast tegelikult siinkandis polnud. Kõik metsa asjad olid tema teha ja ilmaasjata ta naljalt teistega tegemist ei teinud, pigem tallas omaette talle teada radu. Nii et asi oli vist hullem, kui arvata võis.

Veemees tuli uksest välja ja ootas Krobaliku kõrval, kuni Jõnnu lähemale tatsas. Midagi nendes kahes kujus ütles, et päev tuleb tõsisem, kui arvata võis.

Pärast kooli selgus, et maailmal pole häda midagi. Põhjuseks oli keskkond. Oleks ta sattunud Tartu ARSi (tollane kunstitoodete kombinaat) asemel mõnda teise paika, kes teab, mis siis oleks saanud. Tulid aga Tallinnast kolm noort keraamikut: Piret Veski, Kaido Kask ja Maanus Mikkel. Päriskeraamikud olid küll ainult Kask ja Mikkel, Piret Veski oli lõpetanud hoopis klaasikunsti ja hakkas keraamikuks ainult armastuse sunnil. Tegelikult ei olnud neist keegi kindla joonega väljakujunenud kunstnik. Koos ARSis tööle hakates leidis igaüks oma tee, moodustades koos siiski mingi vennaskonna. Asjaosalised on seda meenutanud kui kuldveneaega, kus materjali jätkus ja oli, millega ahjusid kütta. Kõike sai teha, mida tahtsid, ja palka maksti ka veel. Ülemuseks oli väga hea ja positiivne inimene Maia Juhkam, kes oli ise lusti täis ja soosis kõiki noorte tegemisi. Tööd võidi teha ööpäev läbi, igaühel oli oma võti ja ta oli ise oma tegemiste peremees. Kui noor kunstnik tahtis näitust teha, pidid olema tagatud kõik materjalid ja ahjus pidi alati koht olema, et jõuaks ära põletada. See oli ametlik nõue. Pakuti kõige paremat, tee ainult! Ja kõigil oli tahtmist teha.

Piret Õunapuu: Teha tahtmisest kasvasid välja ka näitused?

Maanus Mikkel: See oligi kõige magusam asi. Tol ajal oli mul ikka selline arvamus, et kui sa õige tegija oled, pead aastas ühe näituse tegema. Ja eks sai tehtud ka. Kas üksinda või kolme peale, peaasi, 
et näitus. Minu kõige kärarikkam näitus nendest aegadest oli "Urilugu" (1991) Tartu Kunstimuuseumi Vallikraavi tänava maja teisel korrusel. Sellest kirjutati palju, tehti telesaade ja isegi film. Siis olin ise ka tõesti õhinas. Näituse tegemine oli kõige-kõige tähtsam asi. Sa polnud kunstnik, kui sa näitust ei teinud. Aga eks muidugi oli siis ka lehte ja televisiooni kergem pääseda. Kunst oli siis ikka püha lehm, mida imetleti palju rohkem.

Sinimandria näitus (1992) oli ka võimas. See oli väga uhke koht, nii head galeriid praegu Tartus ei ole. Sealsed avamised olid väga olulised kunstielu sündmused. Kunstirahvas tuli kokku ja isegi tallinlased ei pidanud paljuks siia tulla. Koht oli korralik ja asukoht hea; umbes nagu Vaal-galerii Tallinnas. Õhkkond oli akadeemiline ja väärikas.

Kui näitust teed, siis on su tööl selge suund olemas. Aga võlu on selles, et paned tööd ahjude vahel põranda peale laiali ja vaatad, kuidas läheb, mis mille kõrvale sobib; siis tuleb see õige tunne sisse. Näitus tegelikult ongi oma maailma laiali viskamine.

Näituse tegemine kohustab. Sa paned ruumi kinni ja tärmini paika. Siis teed kontsentreeritult ühte asja. Kui oleks aasta aega, siis läheksin metsa, sest tuleksnii palju muid tuurisid. Peab üks suund nii küpseks saama, et ainult vajutad sama lauluga. Ärkad hommikul üles ja kohe tööle, mitte mingeid muid jante vahele. Kui tuleb midagi vahele, siis võib juhtuda, et see tundub hoopis parem ja kõik varasem kaob ära. Enamasti ei tulegi sellest lõpuks midagi. Kõik peab tulema ühe hingetõmbega.

Piret Õunapuu: Sinu loomingus on tihti tööd moodustanud sarju. Kas sul on peas oma lugu ja sari on selle jutustamise vorm?

Maanus Mikkel: Otsest lugu ma enne välja küll ei mõtle. See on lihtsalt taju. Teed ühe asja ära ja näed, et ta läheb veel sinnapoole ja sinnapoole edasi, ja nii teedki sarja. Siis tuleb suur pealkiri ja alapealkirjad. Üks sari on üks emotsioon. Mul on ju selliseid täiesti üksikult seisvaid töid ka. Enamasti on aga nii, et nagu mulle meeldib padrata, nii saab töidki rohkem, lähevad laiali, siia- ja sinnapoole.

Vaataja võib sinna oma loo välja mõelda, mis mina parata saan. Maailmu on ju palju. Minule on kogu elu meeldinud muinasjutud, sinna tuleb lihtsalt sisse minna. Seda saab võtta kui mingit udust üleminekut tavaelust. Nagu ameerika filmis, et kui on eriti romantiline koht, tuleb piimjas udu. Ma lugesin lapsena muinasjutte ja loen mõnuga tänase päevani. Vapustava mulje jätsid Friedrich Reinhold Kreutzwaldi Eesti rahva ennemuistsed jutud ja eriti seda 
illustreerivad Günther Reindorffi pildid. Kalevipoja lugesin ka siis läbi, kui veel jõmpsikas olin. Indiaanlased tulid alles pärast seda.

See öö polnud just kergemate killast. Sõrm läks suu asemel kogu aeg ninna või silma, nii kaua kui nõianooled lendama hakkasid. Helendavad tulejoad taga lohisemas, tuhisesid need risti-rästi üle Jõnnu pea. Mis asja pärast need teele olid saadetud, sellest vaene mehike aru ei saanudki, põhiline oli mitte jalgu jääda.

"Ära roni kivi peale!" oli Krobalik öelnud tol üle-eelmisel päeval, aga kui vesi ümberringi kerkima hakkas, polnud ju kuhugi mujale minna. Lähedal teisi kõrgemaid kohti polnud, hea et seegi lapike kuiva jalgade alla jäi. Nii ta siis istus ja ootas, kuni madin pea kohalt kuhugi kaugemale hakkas kanduma. Sellevõrra seletas ka silm järjest vähem, lõpuks jäi hoopis vait. Kõrv püsis endiselt kikkis ja kui pimedusest tasast sulpsumist kostis, hakkas Jõnnul jälle hirm. Veemees ei saanud see olla, tema oleks ilma hääleta tulnud, pealegi kahtlustas Jõnnu, et neil Krobalikuga on kusagil veel tõsisemad tegemised käsil. Naine kiviukselt tundus krõbe tegija olevat, sellest juba nii lihtsalt jagu ei saanud.

Vaiksed sulpsud tulid järjest lähemale, lõpuks kolksas midagi kergelt vastu kivi. Silm hakkas jällegi midagi natuke seletama ja seletas tumedat kogu, kes üsna osavalt rahnule hüppas. Jõnnut märgates tõmbus ta kergelt kü̈̈ru ja jäi äraootavalt paigale.

“Kas sina, Jõnnu?” küsis ta lõpuks tasase häälega.

"Jah!" kägises mehike vastu, midagi tuttavat selles hääles igatahes polnud. Kogu tuli lähemale ja patsutas teda rõomsalt õlale. Lõpuks tundis Jõnnu kergendusega ära vana metsavarga, keda ta juba pikemat aega enda koduümbruses kohanud polnud. Mees seletas, et vanas kohas hakanud juba ammu ära tü̈tama, aastaid ka juba üksjagu kukil. Olevat elanud siin üsna rahulikult, aeg-ajalt näpanud küll mõne rondi ja ärinud teisele poole sood maha, aga seda ka rohkem kombe kui vajaduse pärast. Järves oli kala küll ja pisikese maalapi olla ta ka endale üles harinud. Nii et müts seisis rohkem onnis varnas ja häda polnud midagi.

Piret Õunapuu: Sinu enda suhe asjadesse, mida oled teinud?

Maanus Mikkel: Oluline on su oma maailm, see, mida ise oluliseks pead. Minul peab minu maailm ümber olema. Töökoja seinad on täis erinevatest aegadest pärit töid. Kõik need asjad on mingi väikese kõksuga ja see annab mulle võimaluse neid enda ümber hoi- 


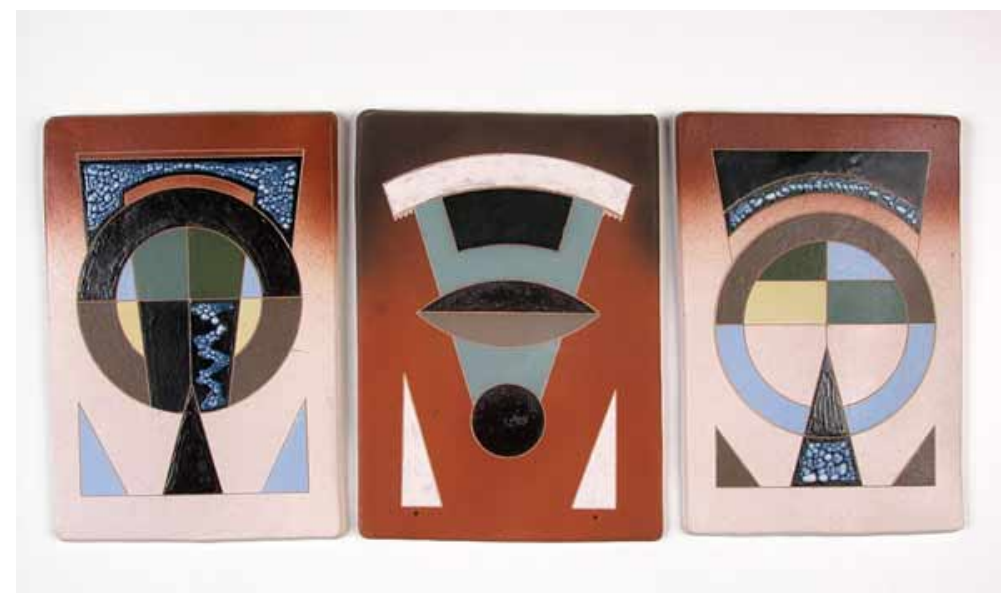

Foto 7. Maanus Mikkel. "Oraakel” II. Madalkuumus. 2001. Anu Ansu foto.

da. Vahel tulen tööle ja lihtsalt istun ja suitsetan ja vaatan neid asju. Kui tuleks mõni hull ja tahaks kõik seinad korraga tühjaks osta, ei läheks kaubaks. Ehk vaid siis, kui ta tõesti hirmus palju raha pakuks. Aga siis istuksin pärast seda siin ööd ja päevad juba ainult sellepärast, et seinad uuesti täis saaksid. Mul lihtsalt peavad tööd ümber olema. Selles, kui asi teise omaks saab, pole midagi kurba, aga vahel on kahju küll. Siis, kui mulle tundub, et on eriti hästi välja tulnud. Keraamiku elus kõige tähtsam on tegelikult see müstiline tuli, mis asja valmis teeb. Ma kujutan küll ette, kuidas mingi taldrik pärast välja näeb, aga tegelikult oled ahju lahti pakkimisel ikka nagu väike tattnina oma sünnipäeva hommikul kingituste kallal. Ja siis juhtub vahel, et mõni asi on isegi palju parem, kui oskasid oodata. Kui see oli näiteks tellimustöö ja kohe viiakse ära, siis on küll hirmus kahju, et ei saanud teist korralikult vaadatagi. Aga asjadel on oma saatus. Ma olen ta valmis teinud ja siis elab ta oma elu. Nagu pojaga, et kui ta ikka läheb merele, siis ta läheb merele ja ulu sina palju tahad.

Piret Õunapuu: Mõnel perioodil on sinu tööd väga sigri-migri-keerulised, vahel aga väga selge joonega. Kas see sõltub sinu elust, mõttest või millest?

Maanus Mikkel: Kui hasarti lähen ja ütlema tahan hakata, siis ta tahab kangesti kõik kohe välja paisata. Võib-olla kütad ühe asja 
peale nii meeletult kokku, et vaatad teda - jumal hoia, palju siia mahub! Tegelikult mulle meeldivad ruutude read, see on lihtne skeem, aga kuidagi paljuütlev. Siis võlus mind ring ja ma mängisin sellega. Kumb rohkem meeldib, ma ei oskagi vahet teha. Mis aktuaalne on, mis pähe lööb, see ongi antud hetkel õige. Nii vinge vend ma veel ei ole, et tõmbaksin savi peale lihtsalt ühe joone, hoolimata sellest, kas see on taldrik või saviplärakas või plaat, ja jaksaksin selle joonega kõik ära öelda.

Kui see veider naisterahvas kusagilt välja ilmus, hakanud asjalood tasapisi imelikuks minema. Ikka rohkem ja rohkem olla mingi võora tegemisi tunda olnud, niikaua kui ühel hommikul järvekaldale kõrge kiviuks kerkinud. Seejärel olla ka naisterahvast ennast pea iga päev näha olnud. Mis asja ta õieti toimetas, sellest ei saanud Näpper (nii tolle selli nimi oli) kuidagi aru. Käis, sinder, ükspäev ringi nagu inetu vanaeit, teisel korral jälle nägi välja nii, et vanamehel kõik ta noorus ühekorraga silma ette tuli. Näpperit ennast ei teinud naine märkamagi ja mingi kõhedus hoidis vana metsavarast ka ise tutvust otsimast. Eks ta oli elu jooksul tundma õppinud, kuskohal targem on kirvest kaukas hoida, ja õieti oli üsna imelik, et ta hoopis uut kohta otsima ei hakanud.

Pardid läksid tasapisi arust ära, munesid, kuhu juhtus, ja poegade eest hoolitsemine käis ka nii, et rohkem pidid need ise oma käe peal hakkama saama. Kalaõnn keeras nii imelikuks, et vanade teadmistega polnud enam suurt midagi peale hakata. Enne vihma ja mõnikord hommikuti tundus, et järves pole enam kalapoegagi, tulipalaval pärastlõunal jällegi juhtus mõnikord nii, et järve end jahutama läinu pidi kabuhirmus kaldale kihutama, nii aplalt kippus kalaparv ujujat piirama. Ja siis pista kas või kaigas vette, ikka hakkas mõni uimeline otsa. Parme ja muid pisemaid vereimejaid näis sigivat nagu küllusesarvest ja aiavili kasvas õige kentsakaks, nii et seda enam õieti suhu pistagi ei julgenud.

Ja too kiviuks oli ka iseäraline. Ühel õhtupoolikul oli Näpper seda lähemalt uurima hiilinud, pärast seda, kui ta naisterahvast üle järve hoopis teisel kaldal toimetamas oli näinud. Uks oli suur ja kõrge, piidad tundusid otse maasügavusest üles kasvavat. Linki, lukuauku ega hingi polnud kusagil leida ja niisugust kergelt krobelist halli pinda ei mäletanud Näpper kunagi 
varemalt näinud olevat. Ega ta väga pikalt uurida julgenudki, sihuke imelikult kõhe tunne oli, nagu jälgiks teda keegi kuskilt paha pilguga.

Neid ja muid asju seletades oli üksjagu aega mööda läinud. Kusagilt hommiku poolt tundus juba midagi helendama hakkavat, kui Näpper järsku püsti kargas.

"Minema siit! Ja ruttu!" sosistas ta ja tõmbas Jõnnut kivi serva poole. Seal hulpis pisike paadinäss, kipakas ja kiivas, ilma et see ühtegi ära oleks kandnud. Näpper kobis kiiresti kivilt paati ja viipas Jõnnule. See tahtis algul vaidlema hakata, aga siis tundis temagi, kuidas kivi üha kiiremini allapoole vajus.

Palusin kunstiteadlasel Tiiu Talvistul hästi lühidalt iseloomustada Maanus Mikkeli loomingut. Vastuseks oli, et kui ei teaks, kes on nende tööde autor, oleks siiski kohe selge, et see on mees, aga mitte naine. See on tõesti väga lühike, aga ometi järele mõeldes täiesti tõene määrang. Suur osa M. Mikkeli loomingust, hoolimata sellest, millises tehnikas see on teostatud, mõjub ekspressiivse, robustsena. Mehelikkust rõhutab krobeline savi ja tihti ka loperdav vorm.

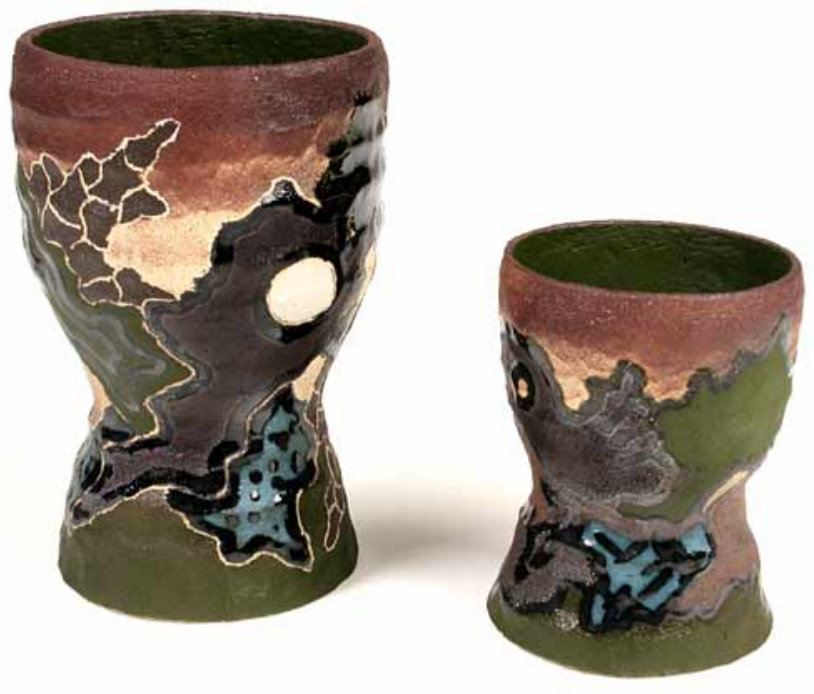

Foto 8. Maanus Mikkel. Karikad. Madalkuumus. 2003. Anu Ansu foto. 


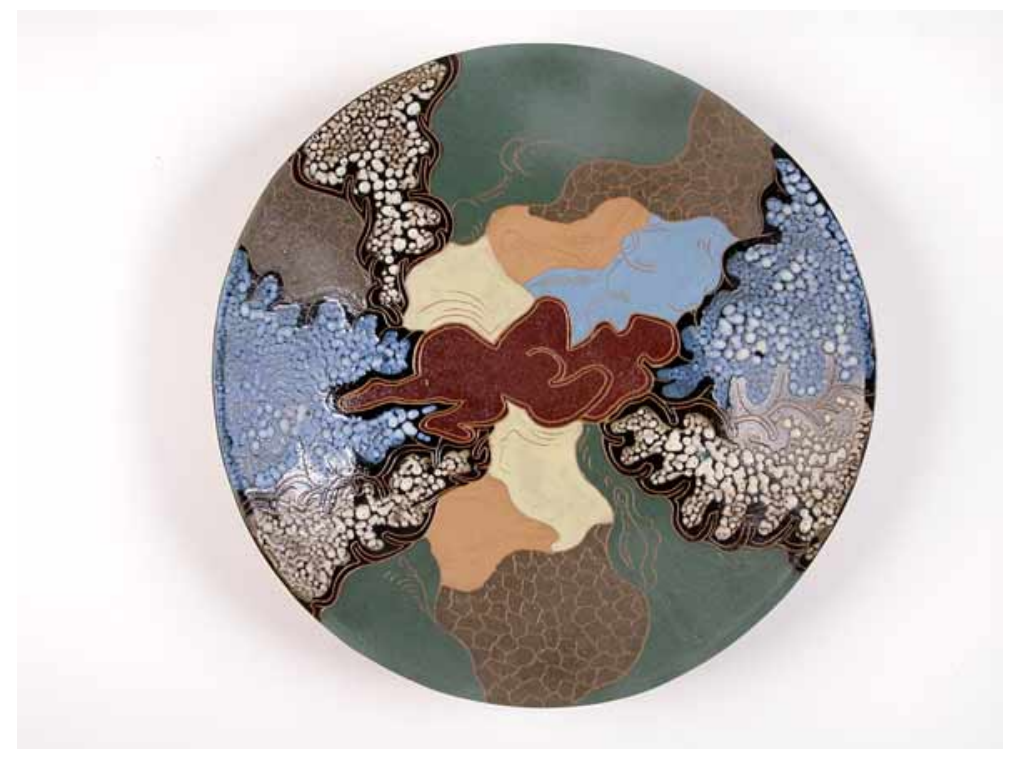

Foto 9. Maanus Mikkel. "Embused". Madalkuumus. 2004. Anu Ansu foto.

Kuigi tihti ei kasutata keraamika dekooris elusolendeid. Maanus Mikkelil on neid olnud peaaegu alati ja tihti on nad päris tundmatut liiki, kuid selgesti tuntavalt elusad. Siia alla kuuluvad nii lendavad lohed kui ka tinglikult eelajaloolised loomad. Neid on aegade jooksul olnud palju, vahepeal olid nad varjusurmas ja nüüd viimasel ajal on nad uuesti välja ilmunud. Arvata on, et tegelased pärinevad jääajaeelsest ürgajast ja suur osa nendest kipub vähekese lendama. Meil tuntud liikidest on armastatud kujud nahkhiir ja kala. Kuigi mõnede kalade puhul on ka selline tunne, et neid pole mõtet vette lasta, tahavad rohkem lennata. Osa varasemate tööde juures on selgelt tunda nn koopajooniste stiili. Selline kujutamisviis on aga järjest vähemaks jäänud.

Kogu sellel ürgugri teemal on juures kübeke rustikaalset groteski. Kujundid on pumbatud suuremaks, juttugi ei ole eestilikust vaoshoitusest. Suurem osa töödest võtab ennast tõsiselt, mõnede puhul on aga sees seda vaikset irooniat, mis vahel suunurgas võbeleb.

Uuteks tegelasteks on hoopis inimesed - mees ja naine. Armastus maailma lõpmatuses. Samuti on varasem tumedam alatoon läinud tüki maad heledamaks. Joon on ümar ja voolav. Kõik on rahul 
ja õnnelikud. Nendest suuremõõtmelistest taldrikutest sai 2003. aastal kokku näitus "Embused". Õnneks ei ole aga ka ürgsed fossiilid täiesti taandunud, nii et võib hoopis väita, et Maanus Mikkeli niigi kirju maailm on ühe tahu juurde saanud.

Kõik läheb edasi, kes teab mis suunas. Täpselt nagu kunstniku kirjutatud jutt Jõnnust, mida igal lugejal on võimalus edasi mõelda.

\section{Kommentaar}

${ }^{1}$ Kursiivikirjas teksti autor on Maanus Mikkel. 